\title{
Contributions to our Knowledge of the Physiology of the Spermatozoa of Ferns.
}

\author{
BY
}

A. H. REGINALD BULLER, B. Sc. (Lond.), Ph. D. (Leip.).

\section{Contents}

$$
\begin{aligned}
& \text { Introduction } \\
& \text { Material and methods . . . . . . . . } 549 \\
& \text { Results . . . . . . . . . . . } 55^{2} \\
& \text { The dissociątion theory and chemotaxis . . . . . } 5^{62} \\
& \text { General points . . . . . . . . : . } 569
\end{aligned}
$$

II. THE WITHDRAWAL OF WATER FROM SPERMATOZOA 572

III. LENGTH OF THE SWARM-PERIOD • • • 575

IV. THE STARCH IN THE VESICLE • . • 579

V. SUMMARY OF THE CHIEF RESULTS • • $\cdot 58$ I

\section{Chemotaxis.}

Introduction. The reaction of free-swimming organisms to chemical stimuli by alteration in the direction of movement is known as chemotaxis. This phenomenon was first generally investigated by $\mathrm{Pfeffer}^{1}$. Its results, although not recognized ${ }^{2}$ as such, had however previously been observed by Stras-

${ }^{1}$ Locomotorische Richtungsbewegungen durch chemische Reize. Untersuchungen aus d. Bot. Inst. zu Tübingen, Bd. i, p. 363, I884. Ueber chemotaktische Bewegungen von Bacterien, Flagellaten u. Volvocineen. Ibid., Bd. ii, p. 352, I888.

${ }^{2}$ Pfeffer, Ber. d. D. Bot. Gesellschaft, I883, p. $5^{24}$.

[Annals of Botany, Vo1. XIV. No. LVI. December, r9o0.] 


\section{Buller.-Contributions to our Knowledge of the}

burger ${ }^{1}$ during the entrance of spermatozoa into the archegonia of Ferns and Marchantia, by Hanstein ${ }^{2}$ at a similar moment in the case of Marsilia, and by Fischer ${ }^{3}$ in the approach of the swarmspores of certain Fungi parasitic on Saprolegniae toward their hosts, while Engelmann ${ }^{4}$ had determined that the unequal distribution of oxygen conditions the movements of Bacteria, \&c. towards air-bubbles or towards a zone in the medium where the oxygen has a particular pressure. The collections of Infusoria and Bacteria at the surface of decaying organic matter observed by Leeuwenhoek, O. F. Müller, Ehrenberg ${ }^{5}$ and Cohn ${ }^{6}$ were also probably in part at least due to chemotaxis ${ }^{7}$.

Stahl ${ }^{8}$ has found that the plasmodia of the Myxomycetes respond to chemotactic stimuli. Massart ${ }^{9}$ and Bordet have shown that this is also true of the leucocytes of the blood.

Pfeffer's experiments were made by a method ${ }^{10}$ at once ingenious and simple. Capillary glass tubes about $8 \mathrm{~mm}$ long and $\frac{1}{10} \mathrm{~mm}$ internal diameter are closed at one end in a gas flame and then placed in a watch-glass. The solution to be tested is poured over the tubes and the watch-glass thereupon set under the bell of an air-pump. On reducing

${ }^{1}$ Strasburger, Jahrb. f. wiss. Bot., 1869-70, Bd. vii, pp. 402 and 418.

${ }^{2}$ Hanstein, Jahrb. f. wiss. Bot., I865-6, Bd. iv, pp. 2 I 9 and 220.

3 Fischer, Jahrb. f. wiss. Bot., I882, Bd. xiii, p. 303.

4 Engelmann, Bot. Zeit., I88I, p. 440. Pflüger's Archiv f. Physiologie, I88I, Bd. xxv, p. 288 ; also Bd. xxvi, p. 54 I.

${ }_{5}^{5}$ Ehrenberg, Die Infusionsthiere als vollkommene Organismen, 1838 , pp. 79 and 80 .

${ }^{6}$ Cohn, Beiträge zur Biologie d. Pflanzen, 1872, Bd. i, Heft 2, p. I42. The observations of Leeuwenhoek and O. F. Müller are here cited.

7 Note.-The collecting of spermatozoa around the egg-cells of Fucus which was observed by Thuret (Annales d. sci. nat., I $854,4^{\circ}$ sér., tome ii, p. 210 ) may also be a chemotactic phenomenon. Strasburger's observations appear to support this supposition (Das bot. Prakticum, 2. Aufl, 1887, p. 402). Bordet however denies that the spermatozoa are chemotactic (Contribution à l'étude de l'irritabilité des spermatozoïdes chez les Fucacées, Bull. de l'Acad. Belgique, $3^{\circ}$ sér., tome xxvii, 1894, p. 889 ).

${ }^{8}$ Stahl, Zur Biologie der Myxomyceten, Bot. Zeit., I884, p. 165.

9 Massart et Bordet, Recherches sur l'irritabilité des Leucocytes, Soc. royale des sc. méd. et nat. de Bruxelles, I89o. See also Gabritchesky, Sur les propriétés chimotactiques des Leucocytes, Ann, de l'Inst. Pasteur, I890, p. 346.

${ }^{10}$ Loc. cit., Bd. i, p. $3^{67}$. 
the pressure of the air the tubes become partly filled with the liquid. A tube is then removed from the solution, washed by dipping in water and placed under the coverglass of a preparation in which spermatozoa or Bacteria, \&c., are swimming. If the solution attracts the organisms they collect in the tube, if it repels them they refuse to enter, while if it does not exert a directive stimulus they move in and out of the tube with apparent indifference. This method has been used by Massart, Voegler, Miyoshi and myself.

Pfeffer's researches were made upon spermatozoa (particularly those of Ferns), swarmspores, gametes, Bacteria, Flagellata, Volvocinia and other Infusoria. He found that as a rule when solutions of neutral substances are sufficiently concentrated they repel the organisms, and was at first of the opinion that the repulsion is simply due to a mechanical ${ }^{1}$ (osmotic) stimulus. Having, however, found exceptions in glycerine, peptone and alcohol in addition to acids and alkalis he finally ${ }^{2}$ attributed the repulsion chiefly, if not entirely, to the chemical qualities of the solutions. Massart ${ }^{3}$ has since made a special study of the action of concentrated neutral substances, and has come to Pfeffer's earlier conclusion that the repulsion is usually an osmotic effect. The reaction to the mechanical stimulus is known as tonotaxis or osmotaxis. Massart made investigations upon a variety of subjects including Bacteria, marine organisms, the muscles of frogs and human eyes. He came to the conclusion that the repulsion of Bacteria, \&c. from neutral salts (when this takes place) is solely due to a negative tonotactic stimulus. Some organisms, however, e.g. Bacterium termo, appear to be quite insensitive to the effect of concentration.

The relation between stimulus and reaction for chemotaxis has been determined by Pfeffer ${ }^{4}$ to be that given in Weber's Law. Although this law has been verified ${ }^{5}$ for a tonotactic

${ }^{1}$ Pfeffer, loc. cit., Bd. i, pp. 455, $480 . \quad 2$ Bd. ii, pp. $623,624,659$.

${ }^{3}$ Massart, Sensibilité et adaptation des organismes à la concentration des solutions salines, Arch. de Biologie, t. ix, I889.

${ }^{4}$ Loc. cit., Bd. i, pp. 395-408.

${ }^{5}$ Rysselberghe, Réactions osmotiques des cellules végétales à la concentration 


\section{Buller.-Contributions to our Knowledge of the}

phenomenon of the cells of higher plants in which the reaction consists of a change of concentration of the cell-sap, this is not yet the case for the tonotaxis of free-swimming organisms. Stange ${ }^{1}$ has shown that the zoospores of some Saprolegniaceae are probably attracted to the dead animal bodies, upon which they settle and develop, by the diffusing phosphates. Miyoshi ${ }^{2}$ has discovered the interesting fact that the sulphur-bacteria are strongly attracted by solutions of hydrogen sulphide.

Miyoshi ${ }^{3}$ has also investigated the phenomenon of chemotropism. He has demonstrated that Fungi penetrate various membranes in response to a chemical stimulus. $\mathrm{I}^{4}$ have shown that this in general is not the case with Bacteria. Researches upon the chemotropism of pollen-tubes have been made by Molisch ${ }^{5}$, Miyoshi ${ }^{6}$ and Lidforss ${ }^{7}$. The tubes are attracted less strongly by sugars and very strongly by certain proteids.

The recent and remarkable papers of Jennings ${ }^{8}$ have thrown

du milieu. Mémoires couronnés et autres Mémoires publiés par l'Acad. roy. de Belgique, I899, t. lviii, p. I.

${ }^{1}$ Stange, Ueber chemotactische Reizbewegungen. Bot. Zeit., Bd. xlviii, I890, p. 107, \&c.

${ }_{2}$ Miyoshi, Studien über die Schwefelrasenbildung u. die Schwefelbacterien der Thermen von Yumoto bei Nikko. Journ. of the Coll. of Sci., Univers. Tōkyō, vol. $x$, Pt. 2, 1897 .

${ }^{3}$ Miyoshi, Die Durchbohrung von Membranen durch Pilzfaden. Jahrb. f. wiss. Bot., Bd. xxviii, I 895 .

- Buller, Die Wirkung von Bacterien auf tote Zellen. Dissertation, Leipzig, 1899.

5 Molisch, Ueber die Ursache der Wachstumsrichtungen bei Pollenschläuchen. Sitzungsber. der Kais. Acad. d. Wiss. in Wien, I889 and I 893 .

6 Miyoshi, Ueber Reizbewegungen der Pollenschläuche. Flora, Bd. 1xxviii, I894, p. 76.

7 Lidforss, Ueber den Chemotropismus der Pollenschläuche. Ber. d. D. Bot. Gesell., I 895 , Bd. xvii, p. 236 .

8 Jennings, Studies on the reactions to stimuli in unicellular organisms :

(I) Reactions to chemical, osmotic, and mechanical stimuli in the Ciliate Infusoria, Journ. of Physiology, vol. xxi, 1897, p. $25^{8}$.

(2) The mechanism of the motor reactions of Paramecium, Amer. Journ. of Physiology, vol. ii, May, I899, p. 3 II.

(3) Reactions to localized stimuli in Spirostomum and Stentor, American Naturalist, vol. xxxiii, May, I899, p. 373 . 


\section{Physiology of the Spermatozoa of Ferns.}

considerable light upon the manner in which the Ciliata and Flagellata respond to chemotactic stimuli. It appears that many of these organisms have a set of reflex movements which can be started by a variety of stimuli such as contact, heat or cold, certain salt solutions, acids, \&c. Although no attention is paid to the position of objects and heat-centres, or to the direction of diffusion of dissolved substances setting up the reflex actions, the nature of the latter is such that the organisms move away from the source of stimulation. The same set of reflex actions is also able to cause an 'attraction' toward solutions, \&c. Such an 'attraction' is, however, only a particular case of a repulsion. While the majority of organisms investigated by Jennings appear to be chemotactic in the above manner, some were found apparently insensible to chemotactic stimuli. It is certain that in chemotropism the organisms concerned seek to grow along diffusion-lines. The existence of free-swimming organisms which are chemotactic in the sense that they move (directly or screw-wise) along diffusion-lines, although sufficiently probable, is not at present definitely known.

Among the many interesting results of Pfeffer's researches was the discovery ${ }^{1}$ that the spermatozoa of the Ferns are strongly attracted by malic acid and its salts. A solution of $0.001 \mathrm{gm}$ per cent. is sufficient to cause a chemotactic reaction. A large number of other substances ${ }^{2}$ were tried but only the nearly related maleic acid ${ }^{3}$ (as a sodium salt) was found to attract, while attraction by sodiummonobromsuccinate ${ }^{4}$ remained doubtful. All the other substances tested, including those most widely found in plant-cells appeared to exert no attractive stimulus whatever. The possibility ${ }^{5}$ of the discovery of other substances which attract was, however, ad-

(4) Laws of chemotaxis in Paramecium, Amer. Journ. of Physiology, May, I 899, p. 355 .

(5) On the movements and motor reflexes of the Flagellata and Ciliata, Amer. Journ. of Physiology, vol. iii, Jan. I900, p. 229.

1 Pfeffer, loc. cit., Bd. i.

3 Loc. cit., Bd. i, p. $3^{82}$.

Loc. cit., Bd. i, pp. 4II-13.

${ }^{5}$ Loc. cit., Bd. i, p. $4^{\mathrm{I}} 2$.

${ }^{4}$ Loc. cit., Bd. ii, p. 655 . 


\section{Buller.-Contributions to our Knowledge of the}

mitted. Sodium maleate was determined to give a much weaker stimulus ${ }^{1}$ than sodium malate. It was also pointed out that it is doubtful if maleic acid and its salts occur in plant-cells while on the other hand malic acid is often abundant in cell-sap, and was shown to occur in a decoction ${ }^{2}$ of prothallia.

As a result of his work Pfeffer came to the well-known conclusion ${ }^{3}$ that it is most highly probable that on the bursting of the archegonia malic acid is the substance liberated which attracts the spermatozoa to the oospheres.

Voegler ${ }^{4}$ has since determined that malic acid, sodium, potassium, ammonium, magnesium and calcium malates give approximately equal attractions. He has also repeated those experiments of Pfeffer according to which the diethylester ${ }^{5}$ of malic acid appears to act indifferently.

During some work upon the spermatozoa of Ferns I have discovered that a number of other substances beside malic acid exert an attractive stimulus. These include organic and inorganic salts (e.g. those of potassium, tartrates, oxalates and phosphates) commonly found in cell-sap. I have compared the stimulus given by about forty different substances, with the remarkable result that the strongest attraction has been found to be given by malic acid and its salts.

The negative results of Pfeffer appear to be due to the fact that his solutions of organic salts ${ }^{6}$ were not sufficiently concentrated, while conclusions were drawn concerning the stimulus given by inorganic salts ${ }^{7}$ from the effect observed with mix-

1 Loc. cit., Bd. i, compare pp. 379-8I and p. 382 .

2 Loc. cit., Bd. i, p. 4I 7 .

${ }^{3}$ Loc. cit., Bd. i, p. $4^{1} 7$ among others. This conclusion may be received 'mit einer an Gewissheit grenzenden Wahrscheinlichkeit' that it is true.

${ }^{4}$ Voegler, Beiträge zur Kenntniss der Reizerscheinungen. Bot. Zeit., Jahrg. xlix, I $89 \mathrm{I}, \mathrm{p} .659$.

${ }_{5}$ Voegler, loc. cit., p. 659 . Pfeffer, loc. cit., Bd. ii, p. 655 .

${ }^{6}$ Pfeffer, loc. cit., Bd. i, p. 4II. The concentrations used were between 0.05 and $0.15 \mathrm{gm} \%$. Spermatozoa are either indifferent to or but very slightly attracted by these solutions.

${ }^{7}$ Loc. cit., Bd. i, p. 4Io. Solutions were made from the ashes of an extraction from grass. The concentration is not stated. The ammonium nitrate added in 
tures. The oversight was rendered all the easier by the relatively strong attraction of malic acid. It was indeed when experimenting with five gm per cent. potassium nitrate that I discovered an attraction by this substance, and was thereby led to make further investigations.

As a result of my work several of Pfeffer's conclusions must undergo modification. Considerable additional probability seems, however, to be given to the supposition that malic acid (in the form of a salt) plays the chief rôle in the attraction of spermatozoa into the archegonia of Fern-prothallia.

When the work was near completion I came to the conclusion that light might be thrown upon the results by an application to them of the electrolytic theory of dissociation of solutions.

Material and Methods. The spermatozoa employed were exclusively those from the prothallia of Gymnogramme Martensii. Leaves of this Fern were plucked and allowed to dry on sheets of paper. The spores so collected were then sown in pots on a substratum of peat mixed with a little sand and soil. The pots were set in a glass case (about $3 \times 2 \times 1 \mathrm{ft}$.) which was situated in a moderately warmed greenhouse and shaded from the direct rays of the sun by shrubs. The air in the case was kept saturated with water vapour.

The spores were usually sown thickly together. When this was so, the prothallia developed a relatively large number of small antheridia. When the spores had been more scattered the prothallia became larger, heartshaped and with relatively less numerous although larger antheridia. The smaller antheridia contained fewer spermatozoa, sometimes only eight or twelve, while the largest contained as many as sixty-four.

When a pot was found to contain prothallia which had produced sufficient antheridia it was brought into the laboratory and placed under a large bell-jar, which was manipulated in such a way that the prothallia continued to grow in relatively dry air. This appears to enable the antheridia to one case would help to obscure the effect, for this substance does not attract. (Vide infra, Table I.) 


\section{Buller.-Contributions to our Knowledge of the}

burst more readily and in greater number when the prothallia are placed in water.

In making the solutions of salt to be tested six concentrations of potassium nitrate were used as standards, namely I, $\frac{1}{10}, \frac{1}{10 \overline{0}}, \frac{1}{1000}, \frac{1}{10000}$, and $\frac{1}{10000}$ gram-molecules ${ }^{1}$ of this substance dissolved in $1000 \mathrm{ccs}$ water. Since the molecular weight of potassium nitrate is IOI the solutions were respectively IO.I, I. I I, O. I, $0.01,0.00 \mathrm{I}$ and $0.000 \mathrm{I} \mathrm{gm} \mathrm{per} \mathrm{cent.}$

The solutions of the other substances were made isotonic with the six standards. As a consequence the solutions in any one vertical row of the Tables I, II, and III taken together are supposed to have an equal attraction ${ }^{2}$ for water.

In calculating the solutions required to be isotonic with the standards the isotonic coefficients of de Vries were employed. De Vries ${ }^{3}$ has shown that the attraction for water of any substance in solution depends partly upon the structure of the molecules. He proved by means of careful and ingenious experiments upon plant-cells that if the plasmolysing power of a molecule of potassium nitrate in a weak solution be supposed equal to 3 , then the plasmolysing power per molecule of any other substance investigated (also in a weak solution) is approximately equal to either $2,3,4$ or 5 . De Vries has called these numbers isotonic coefficients.

Substances in Table I, e.g. sodium chloride, have the isotonic coeff. 3 , those in Table II, e.g. potassium sulphate, the coeff. 4, while for substances in Table III, e.g. canesugar, the coeff. is 2. This being so, it is obvious that to make solutions of sodium chloride, potassium sulphate and cane-sugar isotonic with a solution of potassium nitrate containing $x$ molecules of the salt it is necessary to take $\frac{3}{3} x$ mols sodium chloride, $\frac{3}{4} x$ mols potassium sulphate, and $\frac{3}{2} x$ mols cane-sugar.

\footnotetext{
1 Note.-Instead of writing I gram-molecule in rooo ccs the shorter expression I mol will be subsequently employed in this paper. Cf. Grundriss der allgemeinen Chemie, Ostwald, 3. Aufl, p. 70.

${ }^{2}$ Expressed otherwise as osmotic force or plasmolysing power.

s Hugo de Vries, Eine Methode zur Analyse der Turgorkraft, Jahrb. für wiss. Bot., Bd. xiv, I 884 .
} 
As an illustration of this method of calculation let us suppose it required to make solutions of the three salts just mentioned each isotonic with $\frac{1}{10} \mathrm{~mol}($ approx. $1 \%$ ) potassium nitrate. The molecular weights of sodium chloride, potassium sulphate, and cane-sugar are respectively $58 \cdot 5,174 \cdot 2$, and 342 . One-tenth of the gram-molecules are respectively $5 \cdot 85, \mathrm{I} 7 \cdot 42$, and 34.2 grams. We shall therefore require $\frac{3}{3} \times 5.85 \mathrm{gm}$ sodium chloride, $\frac{3}{4} \times 17.42 \mathrm{gm}$ potassium sulphate, and $\frac{3}{2} \times 34.2 \mathrm{gm}$ cane-sugar dissolved in 1000 ccs or more simply $0.5^{8} 5,2.3$, and $5 . \mathrm{I} \mathrm{gm} \%$ of the three substances respectively.

The above method of calculating isotonic solutions gives approximately accurate results only when the concentrations are neither very high nor very low. De Vries has given the higher ${ }^{1}$ limit as $3 \mathrm{gm} \%$ potassium nitrate (approx. $\frac{3}{10} \mathrm{~mol}$ ). Another and much more accurate method $^{2}$ is based upon our knowledge of the specific molecular conductivity of electricity in solutions at different concentrations. For my purpose, however, as will be clear from the conclusions drawn from the results, the method of de Vries sufficed.

With regard to the chemical aspect of the solutions used it should be observed that in a vertical column of any one table the solutions are isomolecular. In a vertical row of all three tables taken together, however, the solutions in Table I contain more molecules ${ }^{3}$ than those in II and less than those in III. The proportionate number of molecules may thus be represented, Table I : II : III : : I00: $75:$ I50.

When making experiments upon the length of life of the spermatozoa I found that they swarmed about three times as long in hanging drops of tap-water as in similar drops of distilled water. Both Pfeffer ${ }^{4}$ and Voegler ${ }^{5}$ have remarked

1 De Vries, loc. cit., p. 535.

${ }^{2}$ For an application of this method to physiological work and a comparison of its results and those given by the method of de Vries see the paper of Rysselberghe, I899, loc. cit.

${ }^{3}$ i. e. taking no account of their dissociation.

( Pfeffer, loc. cit., Bd. i, p. 368, Anm. 3 .

5 Voegler, Bot. Zeit., I89I, p. 645 . 


\section{Buller.-Contributions to our Knowledge of the}

upon the injurious effects of distilled water. Extremes of heat and exhaustion due to age have been shown ${ }^{1}$ to diminish the sensitiveness of the spermatozoa to chemotactic stimuli. It is, therefore, almost certain that a similar diminution in sensitiveness is caused by an unfavourable medium for swarming. On these physiological grounds, therefore, in all my experiments tap-water was used as the medium into which the spermatozoa were liberated and distilled water avoided. Tap-water is, however, a weak salt solution. That used contained about $0.014 \mathrm{gm}^{\circ}$ mixed salts ${ }^{2}$. All the solutions tested in the capillary tubes were also made with tap-water. The result of this was that the difference in the medium within and without a tube during an experiment was solely due to the extra substance required to be tested ${ }^{3}$.

The prothallia before use were carefully washed in tapwater with the aid of a brush. The coverglasses, usually $12 \mathrm{~mm}^{2}$, were supported by the drops of water and the prothallia. Strips of paper were thus avoided. Each experiment was repeated with several tubes. A general account of the method of use of capillary tubes was given in the introduction. For further details reference may be had to the papers of Pfeffer.

In giving the formulae and molecular weights of substances in the Tables (2nd and 3 rd columns) the water of crystallization has not been stated. The requisite allowance was, however, made when the salts were weighed. The salts and other substances tested were dried with the necessary caution before use.

Results. The first three Tables contain a statement of

Voegler, loc. cit., p. 647 , also p. 659 .

2 The average of two analyses made in March, 1896, and July, 1894, kindly supplied me by Prof. Hofmann of the Institute for Hygiene at Leipzig. The water used was practically neutral in reaction to litmus.

3 The criticism may be offered that in making the solutions with tap-water reactions would in some cases take place which might affect the results. This is true. If, however, the solutions were made with the distilled water, on diffusing out of the tubes reactions would take place with the tap-water outside. I am inclined to think that the conditions under which the spermatozoa swim in nature 
results. The explanation of the terms employed is as follows :-

$$
\begin{array}{ll}
\mathrm{A}=\text { marked attraction. } & \mathrm{R}=\text { repulsion. } \\
\mathrm{a}=\text { weak attraction. } & \mathrm{O}=\text { indifferent. }
\end{array}
$$

$\mathrm{rA}=$ repulsion at first, afterwards strong attraction.

$\mathrm{N}=$ spermatozoa did not collect in the tubes.

- = no experiment made owing to low solubility or acidity of substance.

The third column contains the molecular weights of the salts employed.

When a tube is filled with a solution of a neutral salt which gives a marked attraction (A), the concentration being $\frac{1}{10}$ mol, a few minutes after the beginning of the experiment the spermatozoa are seen collecting at the mouth of the tube and also just inside in considerable numbers. In this diffusion-zone the spermatozoa move backward and forward for some seconds or minutes, being alternately attracted and repelled. It is only after repulsion from a certain diffusion-zone within the tube has taken place several times that the majority of spermatozoa finally enter deeply into the solution. Within one minute after penetrating down the tube they come to rest owing to the withdrawal of water from their protoplasm by the salt solution. Being heavier than the solution they quickly sink to the bottom of the tube, where they may be easily counted. The collections of spermatozoa amount to 100-1000, according to the number liberated from the prothallia and the specific action of each salt.

When a neutral salt which attracts is tested at a concentration isotonic with $\frac{1}{100} \mathrm{~mol}$ potass. nitrate a weak attraction (a) usually takes place. The spermatozoa enter the tube without hesitation at the mouth, the repulsion described above not making itself evident. The attraction, however, only lasts a few minutes. The spermatozoa collect in smaller numbers. They continue their motion in the tube, and when are much more like those here employed than would have been the case if distilled water had been used. 


\section{Buller.-Contributions to our Knowledge of the}

the concentration of the solution has so far sunk that attraction no longer takes place, they may move out again. In several cases I could detect a weak attraction only after repeating the experiments a considerable number of times.

Malic acid and its neutral salts have a strong attraction (denoted by A) at a concentration isotonic with $\frac{1}{1000} \mathrm{~mol}$ potassium nitrate. There is no hesitation in entering the tubes, where the spermatozoa continue to swim for some minutes. In a successful experiment several hundred organisms may be collected.

When a solution acts indifferently the spermatozoa enter the tube occasionally, but do not collect there. If uninjured by the solution they move as readily out of the tube as into it. Indifference may be well observed when the tube contains tap-water. In making the experiments this control was often employed.

A repulsion denoted by $R$ is always very definite. The substances (two acids and an acid salt) found to give such a repulsion also attract at lower concentrations. If a tube contains one of these repellent acid substances at sufficient concentration the spermatozoa are attracted towards the mouth. On reaching a diffusion-zone which causes repulsion the spermatozoa reverse their direction of motion and move rapidly away from the mouth of the tube in a fairly straight line, and thus reach a zone which no longer repels. Here the normal more or less circular direction of motion is resumed. The flight from a repellent zone is easily recognized. Owing to the attraction at low concentrations and repulsion at higher the spermatozoa may collect in a ring outside the tube. The ring indicates the position of a diffusion-zone at the intermediate concentration. During an experiment, owing to diffusion, the zone gradually approaches the mouth of the tube which it may finally enter.

It must be pointed out that the repulsion $\mathrm{R}$ just described differs considerably from the repulsion which makes itself evident in the case of a marked attraction (A) by a neutral 
salt. The repulsion $\mathrm{R}$ is protective, for it prevents the spermatozoa entering too deeply into the acid substances and thus becoming injured. The slight repulsion which occurs during an attraction by a neutral salt is, however, not protective, for the spermatozoa finally enter too deeply into the tube, where they are immediately brought to rest from loss of water.

The repulsion $\mathrm{R}$ from the acid substances is undoubtedly chemotactic. If it were tonotactic, sugar, asparagin and neutral salts should repel when tested at concentrations isotonic with repellent solutions of the acid substances. A comparison of the data given in the tables makes it evident that this is not the case. The repulsive effect which is to be observed during a marked attraction by a neutral salt may on the other hand be tonotactic. If so the tonotactic repulsion is very slight and easily overcome by the chemotactic attraction.

The term $\mathrm{N}$ has been used to indicate that no collection takes place in the tubes at the concentrations isotonic with I mol potassium nitrate. A collection in these cases appears to be mechanically impossible. If a substance attracts, e. g. potassium nitrate, the spermatozoa may collect in the diffusion-zones outside the mouth of the tube. On approaching the mouth, however, the spermatozoa come to rest owing to the withdrawal of water from their protoplasm. They cannot at best penetrate more than one diameter into a tube, and when they do so are slowly carried out again by currents ? Solutions isotonic with I mol potassium nitrate are comparatively heavy. In consequence they fall with apparent rapidity out of the tubes. This phenomenon prevents the collections of spermatozoa in the less concentrated diffusionzones from being clear. With a solution of $\frac{1}{2} \mathrm{~mol}$ potassium nitrate the collection outside the tube may be definitely observed. At the beginning of the experiment the spermatozoa may penetrate 2-3 diameters down the tube before

1 The outgoing stream on the bottom of the tube and into which the spermatozoa fall after coming to rest. 


\section{$55^{6}$ Buller.-Contributions to our Knowledge of the}

coming to rest, but as a rule are carried out again by currents.

It has been remarked that when spermatozoa pass down a tube containing a neutral salt isotonic with $\frac{1}{10} \mathrm{~mol}$ potassium nitrate they come to rest within one minute. They do not penetrate more than half-way down a tube and usually less. With an isotonic solution of glycerine or alcohol the spermatozoa which have entered a tube accidentally may swim down to the bottom and for some minutes before coming to rest. On entering the alcohol the spermatozoa continue to swim as rapidly as in water. On entering the glycerine, their motion is much less rapid. If a solution of glycerine isotonic with I mol potassium nitrate is in a tube, spermatozoa accidentally entering penetrate somewhat further and move longer than in a similar experiment with the latter salt. With an isotonic solution of alcohol ( 6.9 grams per cent.) the contrast with the neutral salts is very striking. On entering a tube a spermatozoon may move down to the bottom, and for one to five minutes. In a similar experiment with potassium nitrate, as already stated, the spermatozoa at best only penetrate a distance equal to about one diameter and come to rest immediately.

The explanation of the above differences depends upon the rate of penetration of the substances in question through living membranes. Neutral salts, sugar, \&c., penetrate extremely slowly or not at all, glycerine ${ }^{1}$ comparatively quickly, and alcohol ${ }^{2}$ very quickly. A spermatozoon comes to rest when a certain amount of water is withdrawn from it. It seems to follow, therefore, that the distance a spermatozoon may penetrate down a tube depends partly upon the specific rate of penetration through living membranes of the substance tested.

1 De Vries, Ueber den isoton. Coeff. des Glycerins. Bot. Zeit., I888, nos. I5 and 16.

${ }^{2}$ Overton, Ueber die allgemeinen osmotischen Eigenschaften der Zelle, ihre vermuthlichen Ursachen und ihre Bedeutung für die Physiologie. Vierteljahrschrift der Naturforschenden Gesell. in Zürich, xliv, I 899. 
From the facts embodied in the tables it is evident that in addition to malic acid and its salts, a considerable number of organic and inorganic salts often occurring in plant cell-sap also attract spermatozoa. All the organic salts tested were found to attract. These include tartrates, potassium oxalate, potassium acetate, and sodium formate. Among the attracting inorganic salts are phosphates, sulphates, potassium nitrate, and potassium chloride.

TABLE I. Isotonic coeff. $=3$.

\begin{tabular}{|c|c|c|c|c|c|c|c|c|}
\hline $\begin{array}{l}\text { Standard solutions of } \\
\text { Potassium nitrate }\end{array}$ & \multicolumn{2}{|c|}{$\begin{array}{l}\text { in parts of a mol } \\
\text { in grams per cent. }\end{array}$} & $\begin{array}{c}\text { I } \\
\text { IO.I }\end{array}$ & $\begin{array}{l}\frac{1}{10} \\
\mathrm{I} \cdot \mathrm{OI}\end{array}$ & $\begin{array}{l}\frac{1}{10} \overline{1} \\
0.1\end{array}$ & $\begin{array}{l}\frac{1}{1000} \\
0.01\end{array}$ & $\begin{array}{l}10 \frac{1}{1000} \\
0.001\end{array}$ & $\begin{array}{l}10000 \\
0.0001\end{array}$ \\
\hline $\begin{array}{l}\text { Ammonium hydrogen } \\
\text { malate }\end{array}$ & $\mathrm{NH}_{4} \mathrm{C}_{4} \mathrm{H}_{5} \mathrm{O}_{5}$ & ${ }^{\text {I }} 5^{\mathrm{I}}$ & $\mathrm{R}$ & $\mathrm{R}$ & $\mathrm{R}$ & $\mathrm{rA}$ & $a$ & 0 \\
\hline Potassium nitrate & $\mathrm{KNO}_{3}$ & IOI & $\mathrm{N}$ & A & $a$ & 0 & $\circ$ & $\circ$ \\
\hline Sodium nitrate & $\mathrm{NaNO}_{3}$ & 85 & $\mathrm{~N}$ & $\circ$ & $\circ$ & $\circ$ & $\circ$ & $\circ$ \\
\hline Lithium nitrate & $\mathrm{LiNO}_{3}$ & 69 & $\mathrm{~N}$ & $\circ$ & 0 & 0 & ० & $\circ$ \\
\hline Ammonium nitrate & $\mathrm{NH}_{4} \mathrm{NO}_{3}$ & 80 & $\mathrm{~N}$ & $\circ$ & $\circ$ & $\circ$ & $\circ$ & $\circ$ \\
\hline Potassium chloride & $\mathrm{KCl}$ & $74 \cdot 6$ & $\mathrm{~N}$ & A & $\circ$ & $\circ$ & $\circ$ & $\circ$ \\
\hline Sodium chloride & $\mathrm{NaCl}$ & $5^{8.5}$ & $\mathrm{~N}$ & $\circ$ & $\circ$ & $\circ$ & ० & $\circ$ \\
\hline Ammonium chloride & $\mathrm{NH}_{4} \mathrm{Cl}$ & $53 \cdot 5$ & $\mathrm{~N}$ & $\circ$ & $\circ$ & $\circ$ & ० & ○ \\
\hline Rubidium chloride & $\mathrm{RbCl}$ & $120 \cdot 7$ & $\mathrm{~N}$ & A & o & $\circ$ & ० & $\circ$ \\
\hline Potassium bromide & $\mathrm{KBr}$ & II $9 \cdot$ I & $\mathrm{N}$ & A & $\mathrm{a}$ ? & $\circ$ & $\circ$ & $\circ$ \\
\hline Potassium iodide & KI & $166 \cdot I$ & $\mathrm{~N}$ & A & $\circ$ ? & $\circ$ & ० & $\circ$ \\
\hline Potassium chlorate & $\mathrm{KClO}_{3}$ & I 22.6 & - & A & $\circ$ & $\circ$ & $\circ$ & $\circ$ \\
\hline Sodium formate & $\mathrm{NaCHO}_{2}$ & 68 & $\mathrm{~N}$ & A & ० & $\circ$ & $\circ$ & $\circ$ \\
\hline Potassium acetate & $\mathrm{KC}_{2} \mathrm{H}_{3} \mathrm{O}_{2}$ & $98 \cdot I_{4}$ & $\mathrm{~N}$ & A & a & 0 & $\circ$ & $\circ$ \\
\hline
\end{tabular}

Organic substances which act indifferently are grape-sugar, cane-sugar, lactose, amylodextrin, glycerine, alcohol, asparagin, and urea. Inorganic salts not appreciably attracting are the chlorides and nitrates of sodium, ammonium, and calcium, and also lithium nitrate.

Of the four free acids which seem to be the most widely found in cell-sap, namely malic, oxalic, tartaric and citric, only malic acid attracts. 


\section{$55^{8}$ Buller.-Contributions to our Knowledge of the}

In comparing the effect of the stimulus given by different substances, one at once notices the somewhat striking fact that compounds containing the negative radicle of malic acid attract much more strongly than any other tested. In each table is to be found a substance with the acid radicle in question. In Table $I$ it will be noticed that whereas the malate attracts strongly at the concentration $\frac{1}{1000} \mathrm{~mol}$,

TABLE II. Isotonic coeff. $=4$.

\begin{tabular}{|c|c|c|c|c|c|c|c|c|}
\hline $\begin{array}{l}\text { Standard solutions of } \\
\text { Potassium nitrate }\end{array}$ & \multicolumn{2}{|c|}{$\begin{array}{l}\text { in parts of a mol } \\
\text { in grams per cent. }\end{array}$} & $\begin{array}{c}1 \\
10 \cdot 1\end{array}$ & $\begin{array}{l}\frac{1}{10} \\
I \cdot O I\end{array}$ & $\begin{array}{l}\frac{1}{100} \\
0.1\end{array}$ & $\begin{array}{l}\frac{1}{1000} \\
0.01\end{array}$ & $\begin{array}{l}10000 \\
0.001\end{array}$ & $\begin{array}{l}10 \frac{1}{10000} \\
0.0001\end{array}$ \\
\hline Sodium malate & $\mathrm{Na}_{2} \mathrm{C}_{4} \mathrm{H}_{4} \mathrm{O}_{5}$ & $178 \cdot 12$ & $\mathrm{~N}$ & A & A & A & $a$ & $\circ$ \\
\hline Potassium tartrate & $\mathrm{K}_{2} \mathrm{C}_{4} \mathrm{H}_{4} \mathrm{O}_{6}$ & $226 \cdot 2$ & $\mathrm{~N}$ & A & a & $\circ$ & $\circ$ & $\circ$ \\
\hline Sodium tartrate & $\mathrm{Na}_{2} \mathrm{C}_{4} \mathrm{H}_{4} \mathrm{O}_{6}$ & I94.I & $\mathrm{N}$ & A & a & $\circ$ & $\circ$ & $\circ$ \\
\hline Sodium-potass. tartrate & $\mathrm{KNaC}_{4} \mathrm{H}_{4} \mathrm{O}_{6}$ & 210.2 & $\mathrm{~N}$ & A & a & $\circ$ & ० & ० \\
\hline Potassium oxalate & $\mathrm{K}_{2} \mathrm{C}_{2} \mathrm{O}_{4}$ & $166 \cdot 2$ & $\mathrm{~N}$ & A & a & $\circ$ & $\circ$ & $\circ$ \\
\hline Potassium phosphate & $\mathrm{K}_{2} \mathrm{HPO}_{4}$ & $\mathrm{I} 74 \cdot 2$ & $\mathrm{~N}$ & A & $\mathrm{a}$ & $\circ$ & $\circ$ & $\circ$ \\
\hline Sodium phosphate & $\mathrm{Na}_{2} \mathrm{HPO}_{4}$ & 142 & $\mathrm{~N}$ & A & a & $\circ$ & $\circ$ & $\circ$ \\
\hline Ammonium phosphate & $\mathrm{Am}_{2} \mathrm{HPO}_{4}$ & I 32 & $\mathrm{~N}$ & A & a & o & ० & $\circ$ \\
\hline Potassium sulphate & $\mathrm{K}_{2} \mathrm{SO}_{4}$ & I $74 \cdot 2$ & $\mathrm{~N}$ & A & $\mathrm{a}$ & $\circ$ & $\circ$ & $\circ$ \\
\hline Sodium sulphate & $\mathrm{Na}_{2} \mathrm{SO}_{4}$ & $\mathrm{I}_{42}$ & $\mathrm{~N}$ & A & $a ?$ & $\circ$ & $\circ$ & $\circ$ \\
\hline Ammonium sulphate & $\mathrm{Am}_{2} \mathrm{SO}_{4}$ & I $3^{2}$ & $\mathrm{~N}$ & A & $\mathrm{a}$ & $\circ$ & $\circ$ & $\circ$ \\
\hline Caesium sulphate & $\mathrm{Cs}_{2} \mathrm{SO}_{4}$ & $3^{62}$ & $\mathrm{~N}$ & A & $\circ$ & $\circ$ & $\circ$ & $\circ$ \\
\hline Sodium sulphite & $\mathrm{Na}_{2} \mathrm{SO}_{3}$ & I 26 & $\mathrm{~N}$ & A & $\mathrm{a}$ & $\circ$ & $\circ$ & ० \\
\hline Sodium thiosulphate & $\mathrm{Na}_{2} \mathrm{~S}_{2} \mathrm{O}_{3}$ & I 58 & $\mathrm{~N}$ & A & $a ?$ & $\circ$ & ० & $\circ$ \\
\hline Calcium nitrate & $\mathrm{Ca}\left(\mathrm{NO}_{3}\right)_{2}$ & I 64 & $\mathrm{~N}$ & $\circ$ & $\circ$ & $\circ$ & $\circ$ & $\circ$ \\
\hline Calcium chloride & $\mathrm{CaCl}_{2}$ & II 10.9 & $\mathrm{~N}$ & $\circ$ & $\circ$ & $\circ$ & $\circ$ & $\circ$ \\
\hline Potassium carbonate & $\mathrm{K}_{2} \mathrm{CO}_{3}$ & I $3^{8 \cdot 2}$ & $\mathrm{~N}$ & $\mathrm{~N}$ & ० ? & 0 & $\circ$ & $\circ$ \\
\hline
\end{tabular}

and also, although very weakly ${ }^{1}$, at $\frac{1}{10000}$, the other salts at these concentrations do not give an observable reaction. A similar statement is true of Table II, and also of Table III if maleic acid be excepted. Maleic acid, however, only gives a very weak attraction at a concentration isomolecular with

1 Compare Pfeffer, loc. cit., Bd. i, p. 379, and Voegler, Bot. Zeit., I89I, No. 40, p. 659 . 
$\frac{3}{2} \times \frac{1}{1000}$ mol malic acid, and is apparently indifferent at a solution one-tenth as strong which in the case of malic acid gives a just appreciable reaction.

With potassium nitrate I could detect no attraction at $0.05 \mathrm{gm}$ per cent., whereas there is a slight one at $0 . \mathrm{I}$ per cent. The concentration recessary to give a just appreciable reaction lies then between $\frac{50}{10000}$ and $\frac{100}{10000} \mathrm{~mol}$. Malic acid gives a just observable reaction at $0.001 \mathrm{gm}$ per cent.

TABLE III. Isotonic coeff. $=2$.

\begin{tabular}{|c|c|c|c|c|c|c|c|c|}
\hline $\begin{array}{l}\text { Standard solutions of } \\
\text { Potassium nitrate }\end{array}$ & \multicolumn{2}{|c|}{$\begin{array}{l}\text { in parts of a mol } \\
\text { in grams per cent. }\end{array}$} & $\begin{array}{c}\text { I } \\
\text { IO.I }\end{array}$ & $\begin{array}{c}\frac{1}{10} \\
I .0 I\end{array}$ & $\begin{array}{l}\frac{1}{100} \\
0.1\end{array}$ & $\begin{array}{l}\frac{1}{1000} \\
0.01\end{array}$ & $\begin{array}{l}\frac{1}{10000} \\
0.001\end{array}$ & $\begin{array}{l}1 \\
10000 \\
0.0001\end{array}$ \\
\hline Cane sugar & $\mathrm{C}_{12} \mathrm{H}_{22} \mathrm{O}_{11}$ & $34^{2}$ & $\mathrm{~N}$ & $\circ$ & ० & ० & 0 & $\circ$ \\
\hline Grape sugar & $\mathrm{C}_{6} \mathrm{H}_{12} \mathrm{O}_{6}$ & 180 & $\mathrm{~N}$ & $\circ$ & ० & $\circ$ & $\circ$ & $\circ$ \\
\hline Amylodextrin & $\left(\mathrm{C}_{12} \mathrm{H}_{20} \mathrm{O}_{10}\right)_{3}$ & $97^{2}$ & - & $\circ$ & $\circ$ & $\circ$ & $\circ$ & 0 \\
\hline Lactose & $\mathrm{C}_{12} \mathrm{H}_{22} \mathrm{O}_{11}$ & $34^{2}$ & - & o & $\circ$ & ० & o & $\circ$ \\
\hline Glycerine & $\mathrm{C}_{3} \mathrm{H}_{5}(\mathrm{OH})_{3}$ & $9^{2}$ & ० & $\circ$ & $\circ$ & ० & $\circ$ & $\circ$ \\
\hline Ethyl alcohol & $\mathrm{C}_{2} \mathrm{H}_{6} \mathrm{O}$ & $4^{6}$ & $\circ$ & $\circ$ & $\circ$ & $\circ$ & $\circ$ & $\circ$ \\
\hline Asparagin & $\mathrm{C}_{4} \mathrm{H}_{4} \mathrm{O}_{3}\left(\mathrm{NH}_{2}\right)_{2}$ & I 32 & - & $\circ$ & ० & $\circ$ & $\circ$ & $\circ$ \\
\hline Urea & $\mathrm{CO}\left(\mathrm{NH}_{2}\right)_{2}$ & 60 & $N ?$ & $\circ$ & $\circ$ & o & $\circ$ & $\circ$ \\
\hline Malic acid & $\mathrm{C}_{4} \mathrm{H}_{6} \mathrm{O}_{5}$ & I34 & $\mathrm{R}$ & $\mathrm{R}$ & $\mathrm{R}$ & A & a & o \\
\hline Maleic acid & $\mathrm{C}_{4}^{*} \mathrm{H}_{4} \mathrm{O}_{4}$ & II 6 & $\mathrm{R}$ & $\mathrm{R}$ & $\mathrm{R}$ & a & $\circ$ & $\circ$ \\
\hline Tartaric acid & $\mathrm{C}_{4} \mathrm{H}_{6} \mathrm{O}_{6}$ & I $5^{\circ}$ & - & - & ०? & $\circ$ & $\circ$ & $\circ$ \\
\hline Citric acid & $\mathrm{C}_{6} \mathrm{H}_{8} \mathrm{O}_{7}$ & I $9^{2}$ & - & - & ०? & $\circ$ & $\circ$ & $\circ$ \\
\hline Oxalic acid & $\mathrm{C}_{2} \mathrm{H}_{2} \mathrm{O}_{4}$ & 90 & - & - & ०? & $\circ$ & $\circ$ & $\circ$ \\
\hline Magnesium sulphate & $\mathrm{MgSO}_{4}$ & 120 & $\mathrm{~N}$ & A & $\mathrm{a}$ & $\circ$ & $\circ$ & $\circ$ \\
\hline
\end{tabular}

or at a concentration isomolecular with one less than $\frac{1}{10000}$ mol potassium nitrate. A rough estimate gives us, therefore, the result that malic acid attracts at least fifty times more strongly than potassium nitrate.

For the other salts which attract the concentrations necessary to cause a just appreciable attraction have not been precisely determined. They are, however, near those isomolecular with $\frac{1}{100} \mathrm{~mol}$ potassium nitrate, in some cases slightly higher, in most slightly lower. It would seem,

$$
\text { P p }
$$


therefore, a moderate estimate if we conclude that, excluding malates and maleates, malic acid attracts the spermatozoa about fifty times more strongly than any of the other attracting substances tested.

As an illustration of the difference in the strength of attraction, it may be remarked that I have repeated the experiments with potassium tartrate with the greatest care on several different occasions, and have never been able to determine the least attraction at $\frac{3}{4} \times \frac{1}{100 \overline{0}} \mathrm{~mol}$, while with an isomolecular solution of malic acid a strong attraction is always found to take place.

The biological aspect of the above results is interesting. The facts certainly support the supposition of Pfeffer already mentioned, that a substance containing the negative radicle of malic acid is liberated at the bursting of the archegonia, and serves to attract the spermatozoa to the oospheres. It is not impossible, however, that a supplementary rôle may be played in this phenomenon by other substances or another substance such as a tartrate or an inorganic potassium salt.

There are several arguments against the supposition that it is the free acid which attracts spermatozoa to the archegonia. In the first place, Pfeffer ${ }^{1}$ could determine no acid reaction to be given by the liberated cell-sap when the archegonia burst. Secondly, the free acid, even at low concentrations, is very toxic for the spermatozoa, for it shortens their swarm-period considerably. Thus I found that they live about twelve times longer in tap-water than in a solution of tap-water containing $0.01 \mathrm{gm}$ per cent. malic acid. For the purpose of the third argument it is necessary to give the data showing the manner in which the stimulus of malic acid varies with the concentration. In Table $I V: R=$ repulsion, $\mathrm{A}=$ marked attraction, $\mathrm{a}=$ weaker attraction, $\mathrm{R}-\mathrm{A}=$ repulsion at first quickly followed by strong attraction, $\mathrm{o}=$ indifferent. The solutions are given in grams per cent.

1 Loc. cit., Bd. i, p. $4^{18}$. 
TABLE IV. Malic acid.

\begin{tabular}{|l|c|c|c|c|c|c|c|c|}
\hline Concentration & $\mathrm{I} \cdot 0$ & 0.05 & 0.04 & 0.03 & 0.02 & 0.01 & 0.001 & 0.0005 \\
\hline Stimulus & $\mathrm{R}$ & $\mathrm{R}$ & $\mathrm{R}$ & $\mathrm{R}-\mathrm{A}$ & $\mathrm{A}$ & $\mathrm{A}$ & $\mathrm{a}$ & 0 \\
\hline
\end{tabular}

From the results given in the table it will be noticed that a repulsion takes place at $0.03 \mathrm{gm}$ per cent. Now Pfeffer ${ }^{1}$ found that if prothallia are placed in a solution of $0.01 \mathrm{gm}$ per cent. sodium malate the spermatozoa liberated are still just observably attracted into the archegonia. He has also found ${ }^{2}$ that if any solution $x$ of the malate be used outside a capillary tube as a medium in which the spermatozoa swim, then, in order to obtain an observable reaction it is necessary to place in the tube a solution $=30 x$. When, therefore, he finds that if the medium contains $0.0 \mathrm{I}$ per cent. sodium malate, an attraction ${ }^{3}$ into the archegonia still takes place, we are justified in accepting his conclusion that the least concentration of the malate liberated is 0.3 per cent. It may, however, be deduced from Table IV that a solution of the free acid isomolecular with 0.3 per cent. sodium malate strongly repels. It is therefore evident that it is not the free acid which plays the chief rôle in the attraction of spermatozoa into the archegonia. It is much more probably one or more neutral salts.

Pfeffer ${ }^{4}$ tested various proteids and sugars (see also Table IV) and was unable to find any which attracted the spermatozoa of Ferns. At present the substances known to attract may be classed as organic acids, organic salts and inorganic salts. The chemotropism of pollen-tubes offers an interesting contrast to the chemotaxis of the spermatozoa. Chemotropic deviations are caused by proteids ${ }^{5}$ and sugars, and as yet no salt or acid has been found to attract.

Pollen-tubes pass from the stigma to the ovules by growth. It should not, therefore, be surprising that the food-stuffs-

1 Loc. cit., Bd. i, p. 4 I 8.

3 Loc. cit., Bd. i, p. 4 I 8.

${ }^{2}$ Loc. cit., Bd. i, p. $39^{8}$.

4 Bd. i, pp. 41 2-4I3.

${ }^{5}$ Lidforss, loc. cit., p. 237 .

P P 2 


\section{Buller.-Contributions to our Knowledge of the}

proteids and sugar-on which the tube lives, are also employed $^{1}$ in giving the chemotropic stimulus. On the other hand, the spermatozoa of the Ferns have stored within them sufficient energy to reach the oospheres without the help of any additional food-supply from without. It is therefore not essential that the substance (or substances) liberated from the archegonia should possess a high value as food. Malates might therefore be employed to attract the spermatozoa. The acid radicle of malic acid is present in a decoction ${ }^{2}$ of prothallia, and is doubtless a normal product of the metabolism of the cells. This fact helps to explain why in all probability a malate is set free from the archegonia in order to attract the spermatozoa.

The dissociation theory and chemotaxis. The theory of electrolytic dissociation of solutions has been successfully employed in estimating the toxic effect of various substances upon higher plants ${ }^{3}$, Bacteria ${ }^{4}$, and Fungi ${ }^{5}$.

The first suggestion that chemotaxis may to a certain extent be elucidated by the dissociation theory is due to Ostwald ${ }^{6}$. This physical chemist explains the fact, discovered by Pfeffer, that the salts of malic acid attract the spermatozoa of Ferns with about equal strength, whereas the diethylester does not attract at all, on the supposition that in the salt solutions the negative radicle is free as an ion, and in this form attracts, while in the ester solution it is not free, this substance being undissociated.

In a recent paper by Jennings ', entitled 'The Laws of chemotaxis in Paramecium,' an endeavour was made to

1 Lidforss, loc. cit.

${ }^{2}$ Pfeffer, Bd. i, p. $4 \mathrm{r} \%$.

${ }^{3}$ Kahlenberg and True, On the toxic action of dissolved salts and their electrolytic dissociation. Bot. Gaz., Vol. XXII, I896, p. 8I. Heald, On the toxic effect of dilute solutions of acids and salts upon plants. Ibid., p. I25.

* Krönig u. Paul, Die chemischen Grundlagen der Lehre von der Giftwirkung

u. Desinfektion. Zeit. f. Hygiene u. Infect., Bd. xxv, I897, p. I.

${ }^{5}$ Clark, Electrolytic dissociation and toxic effect. Jour. of Phys. Chem., Vol. III, I899, p. 263.

- Ostwald, Referat, Zur Pharmakologie des Quecksilbers, E. Dreser, Zeit. f. phys. Chem., Bd. xiii, 1894 , p. 378 .

"Jennings, Study IV. loc. cit., May, I899. 


\section{Physiology of the Spermatozoa of Ferns. 563}

explain the results with sixty-five compounds by the help of a chemical theory. Unfortunately the attempt miscarried, 'owing to a chemical misinterpretation as to the facts which give solutions their characteristic properties.' In a footnote of a subsequent paper ${ }^{1}$ Jennings has partially corrected his earlier criticism. The results of his work seem to leave little doubt that the chemotaxis of Paramecium follows certain laws to which the dissociation theory gives a clue. The theory has also been applied by Garrey ${ }^{2}$ to the chemotaxis of Chilomonas.

It must not be assumed that a chemotactic stimulus may be given only by ions. Just as some undissociated substances, such as alcohol, have a toxic action, so one finds undissociated substances giving a chemotactic stimulus. Thus, for instance, Pfeffer found that the ${ }^{3}$ spermatozoa of Mosses are attracted by cane-sugar which is not dissociated, and his further work upon Bacteria has shown that a single species, e. g. ${ }^{4}$ Bacterium termo, is attracted by a number of undissociated substances e. g. grape sugar, dextrin, milk sugar, mannit and asparagin in addition to such highly dissociated substances as sodium chloride, potassium nitrate and potassium sulphate.

In testing the toxic action of solutions it appears to have been determined in some cases at least that even where the substance is highly dissociated the undissociated molecules ${ }^{5}$ have a toxic effect. We must therefore admit that when a highly dissociated salt (e.g. potassium nitrate as a $\mathrm{I} \%$ solution) attracts spermatozoa, the small percentage of undissociated molecules may have a chemotactic action.

${ }^{1}$ Study, V, On the movements and motor reflexes of the Flagellata and Ciliata. Amer. Jour. of Physiology, Jan., I900. The footnote on p. 236 contains the above citation.

${ }^{2}$ Garrey, The effect of ions upon the aggregation of Flagellated Infusoria. Amer. Jour, of Physiology, Vol. III, p. 239, Jan., I900.

Note. The papers of Jennings and Garrey came to my knowledge after this section of my paper was written. It has been altered only in so far as it was thought necessary to acknowledge their work. Garrey's paper appeared six months after my work was brought to a conclusion.

${ }^{3}$ Pfeffer, loc. cit., Bd. i, p. 43 .

${ }^{5}$ Clark, loc. cit., pp. 282, 287, \&c.

t Ibid., Bd. ii, pp. 603-605. 
In Tables I and II it will be noticed that, whereas potassium nitrate attracts, the nitrates of sodium, lithium, ammonium and calcium do not, and that while potassium chloride attracts this is not the case with the chlorides of sodium, ammonium and calcium.

The solutions of these salts are ionized, the ions being in each case the negative radicle and the metal. The amount of ionization is considerable. At a concentration isomolecular with $\frac{1}{10}$ mol potassium nitrate ${ }^{1}$, it is $70-86 \%$ of the molecules in solution, while at lower concentrations it is of course still higher. From the fact that the solutions of sodium, ammonium, lithium and calcium nitrates and also sodium, ammonium and calcium chlorides do not attract it would seem justifiable to conclude that neither the ions $\mathrm{Na}^{+}, \mathrm{NH}_{4}^{+}$, $\mathrm{Li}^{+}, \mathrm{Ca}+, \mathrm{Cl}^{-}, \mathrm{NO}_{3}$ nor the whole molecules $\mathrm{NaCl}, \mathrm{NH}_{4} \mathrm{Cl}$, $\mathrm{CaCl}_{2}, \mathrm{NaNO}_{3}, \mathrm{NH}_{4} \mathrm{NO}_{3}, \mathrm{LiNO}_{3}, \mathrm{Ca}\left(\mathrm{NO}_{3}\right)_{2}$ give a positive chemotactic stimulus.

Potassium nitrate and potassium chloride both attract. If, however, the ions $\mathrm{Cl}^{-}$and $\mathrm{NO}_{3}^{-}$do not attract it is evident that the attraction of these salts is due to the ion $\mathrm{K}^{+}$or possibly to the whole molecules $\mathrm{KNO}_{3}$ and $\mathrm{KCl}$ or to the combined effect of the $\mathrm{K}^{+}$ions and the respective whole molecules. At a concentration of $\frac{1}{10} \mathrm{~mol}$, potassium nitrate is ionized to the extent of approx. $81 \%$ and potassium chloride to $86 \%$. Owing to this high dissociation and also to the known chemical activity of the ions in a solution it seems to me that we may neglect the second possibility and assume that it is highly probable that the ion $\mathrm{K}^{+}$gives a positive chemotactic stimulus.

If $\mathrm{K}^{+}$ions attract, it is reasonable to suppose that any other neutral salt of potassium in which the ion $\mathrm{K}^{+}$is present also attracts. So far as my experiments have gone with nine other potassium salts this supposition has been justified. Thus attraction is given by solutions of potassium iodide, bromide, sulphate, chlorate, phosphate $\left(\mathrm{K}_{2} \mathrm{HPO}_{4}\right)$, tartrate, acetate, oxalate and sodium potassium tartrate.

${ }^{1}$ Calculated from the tables in 'Solution and Electrolysis.' Whetham, I 895. 
The strongly alkaline potassium carbonate does not attract. This is not surprising on account of the fact that this substance (owing to hydrolysis ${ }^{1}$ and consequent formation of $\mathrm{O} \mathrm{H}^{-}$ions) exercises a strongly toxic effect upon spermatozoa at a concentration below that probably necessary for the ion $\mathrm{K}^{+}$to give an appreciable attraction.

The following ${ }^{2}$ substances give attractions of approximately equal strength : malic acid, ammonium hydrogen malate and the malates of sodium, potassium, ammonium, calcium, barium and magnesium. All these substances are dissociated and each contains the negative radicle of malic acid, $\mathrm{C}_{4} \mathrm{H}_{4} \mathrm{O}_{5}^{=}$. They attract, as already mentioned, much more strongly than any other substances which do not contain the radicle in question. Some of the bases, namely sodium, ammonium and calcium, when occurring as ions in solution, according to my previous argument do not appear to appreciably attract at all. We may therefore conclude that the $\mathrm{C}_{4} \mathrm{H}_{4} \mathrm{O}_{5}^{=}$ions attract.

Although we have good reason to suppose that the ion $\mathrm{K}^{+}$ attracts, solutions other than malates containing $\mathrm{K}^{+}$ions cease to attract at the concentration approx. $\frac{1}{200} \mathrm{~mol}$. Potassium malate, however, attracts at $\frac{1}{10000} \mathrm{~mol}$. It appears, therefore, that at this concentration potassium malate owes its attraction entirely to the $\mathrm{C}_{4} \mathrm{H}_{4} \mathrm{O}_{5}^{=}$ions, while the $\mathrm{K}^{+}$ions are practically chemotactically inactive. It is doubtless due to the indifference of all the kations at low concentrations that all malates attract with about equal strength.

If it is the ion $\mathrm{C}_{4} \mathrm{H}_{4} \mathrm{O}_{5}^{=}$of malic acid which is responsible for the attraction of this substance it is no matter for surprise that when this group of atoms is present in an undissociated compound, attraction no longer takes place. This happens in the case of the di-ester of malic acid, as was pointed out by Ostwald. Both Pfeffer ${ }^{3}$ and Voegler ${ }^{4}$ found that this substance

${ }_{1}$ Ostwald, Grundlinien der anorganischen Chemie, I900, pp. 255, 256.

${ }^{2}$ Compare Tables I, II, and III ; Pfeffer, loc. cit., Bd. i, p. $3^{8 I}$; and Voegler, loc. cit., p. 659 .

3 Bd. ii, p. 655 . ( $1 \%$ and $0.1 \%$ solutions were tried.)

" Voegler, loc. cit., p. 659. 


\section{Buller.-Contributions to our Knowledge of the}

does not attract the spermatozoa. It is still less astonishing that asparagin, which may be written as an amide-derivative ${ }^{1}$ of malic acid, does not attract, for not only is this compound practically undissociated, but the group of atoms which forms the negative radicle of malic acid is no longer present.

Five sulphates have been tested, namely, those of sodium, potassium, ammonium, magnesium and caesium. They all attract. From what has already been said about the ions $\mathrm{Na}^{+}$and $\mathrm{NH}_{4}^{+}$it follows that we must attribute the attraction of sulphates to the negative radicle. It seems, therefore, very probable that the ion $\mathrm{SO}_{4}^{=}$attracts.

A similar argument may be applied to the phosphates and tartrates. Their attraction is probably due to the respective anions.

With regard to the ions of other neutral salts, there is not sufficient evidence to draw any very definite conclusions. From the fact, however, that sodium formate, sodium sulphite and sodium thio-sulphate attract, it appears probable that the respective anions give a positive chemotactic stimulus. There is at present no evidence to indicate the action of the ions $\mathrm{Br}^{-}, \mathrm{I}^{-}, \mathrm{ClO}_{3}^{-}, \mathrm{C}_{2} \mathrm{H}_{3} \mathrm{O}_{2}^{-}$and $\mathrm{C}_{2} \mathrm{O}_{4}^{=}$.

The eight undissociated substances tested namely, cane sugar, grape-sugar, lactose, amylodextrin, alcohol, glycerine, asparagin and urea, agree in not attracting the spermatozoa. The indifference of the carbohydrates is remarkable, in view of the fact that the spermatozoa of the Mosses are attracted by cane-sugar. Undissociated substances may yet be discovered which attract the spermatozoa of Ferns. Such substances will probably not be found among sugar or alcohols, owing to the fact that cane-sugar, grape-sugar, lactose and amylodextrin on the one hand and ethyl-alcohol and glycerine on the other act indifferently.

A comparison may now be made between salts and acids. In Table II it will be seen that sodium malate attracts at the concentrations isotonic with $\frac{1}{10}, \frac{1}{100}, \frac{1}{100 \overline{0}}$, and $\frac{1}{10000} \mathrm{~mol}$

1 Asparagin is, however, to be regarded as the monamide of amido-succinic acid. Höllemann, Lehrbuch d. organ. Chemie, I899, p. 221. 
potassium nitrate. If the concentrations are doubled so that they become isomolecular with the solutions in Table III attraction still takes place at the new concentrations. Sodium malate attracts therefore in solutions isomolecular with $\frac{3}{2} \times \frac{1}{10}$, $\frac{3}{2} \times \frac{1}{100}, \frac{3}{2} \times \frac{1}{1000}, \frac{3}{2} \times \frac{1}{10000} \mathrm{~mol}$ malic acid. The free acid however, while attracting at the two latter concentrations, repels at the two higher. Sodium hydrogen malate and maleic acid behave in a similar manner. Common to these three acid substances in solution is the ion $\mathrm{H}^{+}$, whereas in the neutral salts it is absent. One would suppose, therefore, that the ion $\mathrm{H}^{+}$is responsible for the repulsion.

If however the ion $\mathrm{H}^{+}$is the cause of repulsion, we might also expect to find that other acids such as tartaric, oxalic, and citric repel. This supposition I have not as yet verified. I was able to"satisfy myself that these three acids do not attract, but remained in doubt ${ }^{1}$ whether they repel or are chemotactically indifferent. According to $\mathrm{Pfeffer}^{2}$, however, citric acid repels. From his work with Bacteria, \&c., he came to the conclusion ${ }^{3}$ that repulsion by acids at sufficient concentration is a general phenomenon. Jennings has found that Paramecium is repelled by all acids at the necessary concentration. We have, therefore, considerable support for the supposition that the ion $\mathrm{H}^{+}$is the cause of repulsion from acids.

Reference has already been made to the ring-collections which may be obtained in an experiment with a strong solution of malic acid. A ring-collection is due to the fact that malic acid attracts at low concentrations and repels at higher. The part played by the ions may perhaps be explained in the following manner. At $0.03 \%$ malic acid (see

1 At this point in the research the material unfortunately became attacked by a Fungus, and in consequence the spermatozoa available for any given preparation were not numerous enough to decide the question. A repulsion is easy to observe when there is also an attraction because the spermatozoa collect in the intermediate diffusion zone. When there is no such attraction a repulsion must undoubtedly be much more difficult to observe. When Bacteria are used the detection of a repulsion with a substance that does not attract is much easier owing to the enormous number of individuals one may employ.

${ }^{2}$ Pfeffer, loc. cit., Bd. i, p. $3^{8} 7$. ${ }^{3}$ Ibid., Bd. ii, p. 659 . 


\section{Buller.-Contributions to our Knowledge of the}

Table IV) the attraction of the $\mathrm{C}_{4} \mathrm{H}_{4} \mathrm{O}_{5}^{=}$ions equals the repulsion of the $\mathrm{H}^{+}$ions. At concentrations below this, owing to the specific reaction of the spermatozoa, the combined attractive effect of the $\mathrm{C}_{4} \mathrm{H}_{4} \mathrm{O}_{5}^{=}$ions is greater than the combined repulsive effect (if such there is) of the $\mathrm{H}^{+}$ions. The spermatozoa, therefore, collect in weak solutions of the acid. At concentrations above $0.03 \%$ the combined repulsive effect of the $\mathrm{H}^{+}$ions becomes greater than the combined attractive effect of the $\mathrm{C}_{4} \mathrm{H}_{4} \mathrm{O}_{5}^{=}$ions. A repulsion therefore takes place ${ }^{1}$.

Engelmann ${ }^{2}$ discovered that Bacteria are attracted by oxygen dissolved in water at a certain pressure and repelled when the pressure exceeds a certain limit. In this case the same molecules evidently give a positive or negative chemotactic stimulus according to their concentration.

Rubidium chloride attracts. If my argument that the $\mathrm{Cl}^{-}$ ion is inactive is correct, it is very probable that the $\mathrm{Rb}^{+}$ions are responsible for the attraction. The ions $\mathrm{Rb}^{+}$and $\mathrm{K}^{+}$ attract, while the ions $\mathrm{Na}^{+}, \mathrm{NH}_{4}^{+}$and $\mathrm{Li}^{+}$do not. The grouping of these elements agrees with that given in the Periodic Law.

It is now necessary to make some remarks upon the nature of an 'attraction.' Owing to the fact that the papers of Jennings (loc. cit.) came to my notice when too late, I made no special study of the motor reactions of the spermatozoa, but assumed that an attraction is due to a sensitiveness and consequent reaction on the part of the organisms to a gradation in concentration along the surface or in the substance of their bodies. If this theory is correct an attraction is directly caused by a solution in which the spermatozoa collect. There is but one external stimulus. It is this, which my application of the dissociation theory may concern. The stimulus just suggested is, however, according to the observations of Jennings ${ }^{3}$, not the cause of chemotactic

1 This explanation may be somewhat more complicated, but not different in nature, owing to the fact that malic acid dissociates in stages.

2 Engelmann, Zur Biologie der Schizomyceten. Pflüger's Archiv f. Physiologie, I 88 r, Bd. xxvi, p. 54 r.

3 Jennings, Studies II and V, loc. cit. 
movements in the Flagellata and Ciliata. A collection of these organisms in a drop introduced into the medium where they are swimming takes place as follows. (I) The organisms enter the drop accidentally, (2) the drop acts upon the organisms, (3) in consequence, when they accidentally approach their previous medium it repels them. Here there are two distinct kinds of action. The drop is responsible for the first, and the previous outer medium for the second. If the motor reactions of the spermatozoa are of the same nature as those of the Ciliata and Flagellata it must be understood that when, in the application of the dissociation theory, ions or molecules are said to 'attract,' this means that they give rise to the first of the two actions.

In conclusion it must be pointed out that in discussing the attraction of neutral salts I have been unable to state whether the whole molecules play any chemotactic rôle. The omission is, however, rendered less serious by two considerations. Firstly, owing to the high dissociation at the low concentrations used, the number of whole molecules in any unit volume of a solution is usually very much less than the number of ions. Secondly, the ions in any solution are supposed by chemists ${ }^{1}$ to be responsible for its chemical reactions. The assumption that the attraction by a neutral salt is practically due to one or both ions is therefore to a considerable extent justified. Since, however, in the work upon toxicity (loc. cit.) it has been shown that whole molecules in a dissociated solution are poisonous and therefore have a physiological action, no application of the dissociation theory to chemotaxis can be considered complete until it has been determined what effect, if any, is due to the whole molecules.

Genoral Points. If it is desired to determine whether a neutral salt attracts or not, experience teaches us that this may best be attempted by trial at a concentration of about $\frac{1}{10} \mathrm{~mol}$.

${ }^{1}$ E. g. Ostwald, Grundriss der Allgemeinen Chemie, I $^{\text {st }}$ Aufl, 1889 ; also Whetham, Solution and Electrolysis, Cambridge, I895, p. 165. 


\section{Buller.-Contributions to our Knowledge of the}

It was ingeniously proposed by Pfeffer $^{1}$ to use spermatozoa as a test for malic acid in the cell-sap of plants. $\mathrm{He}$ brought broken cells into a medium in which spermatozoa were swimming, and found that the latter were attracted by the diffusing cell-sap. He therefore concluded that malic acid was present in the cells. Since, however, it is now known that many other substances widely occurring in cell-sap such as tartrates, potassium oxalate, phosphates, \&c., attract spermatozoa at fairly low concentrations $\left(\frac{1}{100}\right.$ $\mathrm{mol}$ ), this test for malic acid in cell-sap cannot be considered decisive.

The cell-sap of a petiole of Gunnera scabra ${ }^{2}$ contained, according to an analysis of de Vries: $0.56 \mathrm{gm} \%$ of substances containing the negative radicle of malic acid, 0.67 $\mathrm{gm} \%$ potassium chloride, $0.01 \mathrm{gm} \%$ potassium phosphate, and $0.56 \mathrm{gm} \%$ glucose. Such a cell-sap would undoubtedly attract spermatozoa. The chief rôle in the attraction would be played by the malic acid compounds. The potassium chloride would, however, also attract strongly. The glucose would have no action whatever.

Another analysis of de Vries showed that the growing point of the stem of Helianthus tuberosus contained $0.9 \mathrm{I}$ $\mathrm{gm}^{\circ} \%$ potassium nitrate. This is sufficient to cause a strong attraction, as is evident from Table I. From the cases of Gunnera, Helianthus, and others which cannot be quoted here, and from the fact that many substances determined to give a positive chemotactic stimulus, such as tartrates, oxalates, potassium salts, \&c., occur very frequently in plant-cells, we may conclude that the attraction given by any cell-sap is not necessarily due to malic acid compounds, and may take place in their absence.

Pfeffer determined an attraction by the cell-sap of all the plants (about thirty) which he employed for his experiments. The plants included Algae, Fungi, Mosses, Ferns, Gymno-

\footnotetext{
1 Pfeffer, loc. cit., Bd. i, p. 4I 3 .

${ }^{2}$ De Vries. Eine Methode zur Analyse der Turgorkraft, Jahrb. f. wiss. Bot., Bd. xiv, I884, p. 574 .
} 
sperms, and Angiosperms. That the attraction was so general suggests that other substances beside malic acid compounds may have taken part in giving the results.

Not every solution of mixed salts, one or more of which latter attract, is capable of giving an appreciable attraction. Thus with a nutrient solution for higher plants I could not determine an attraction at any concentration. The salts were present in the following proportions by weight : calcium nitrate 100 , potassium nitrate 25 , sodium chloride 15 , magnesium sulphate $5 \circ$, and potassium phosphate $\left(\mathrm{KH}_{2} \mathrm{PO}_{4}\right) 25$. An attraction might have been expected from the presence of the potassium salts. Its absence was probably due to the acid reaction of the phosphate. It is doubtful whether the non-attracting calcium nitrate and sodium chloride affected the result.

When the spermatozoa are liberated in distilled water I could determine no attraction by tap-water or by water from a small pond. These weak salt solutions are not sufficiently concentrated to give any chemotactic effect, although individual salts which they contain (when more concentrated) certainly attract. In these experiments the prothallia were cleaned as thoroughly as possible in distilled water before the spermatozoa were liberated.

Rubidium chloride was found to attract spermatozoa about as strongly as potassium chloride. Since other chlorides tested do not attract, the stimulus given by rubidium chloride appears to be due to the metal. Rubidium is a rare metal and only present in very minute quantities in the soil. When one reflects upon the kind of substratum upon which prothallia grow, it seems extremely improbable that rubidium salts ever gain access to the water-drops in which spermatozoa swim in sufficient quantity to cause attraction. We appear therefore to have, in my experiment with rubidium chloride, a case of a reaction to a stimulus without any special biological significance. Parallel cases seem to be given in the response of roots to the stimulus of light, electric currents and slow currents of water by alteration in the 


\section{Buller.-Contributions to our Knowledge of the}

direction of growth. Perhaps these useless reactions ${ }^{1}$ are to be explained upon a theory of physiological correlation. The acquirement of one function may necessitate the acquirement of another The apparatus required for the reception interpretation and reaction in the case of one stimulus may be of such a nature that it may be set in motion by another stimulus. Thus the apparatus acquired for performing biologically useful movements by response to malic acid may be such in the case of the spermatozoa of Ferns that it can also be employed by rubidium chloride to give directive movements which have no biological advantage.

\section{The Withdrawal of Water from Spermatozoa.}

When a certain amount of water is withdrawn from spermatozoa they come to rest entirely. If after having been brought to rest in this way the spermatozoa are again allowed to absorb water freely, resumption of movement may take place. Similar facts have been observed for Bacteria ${ }^{2}$ and other organisms.

When a spermatozoon enters a capillary tube which contains a concentrated solution of a neutral salt, e.g. $5 \mathrm{gm} \%$ potassium nitrate, it moves slower and slower until, upon penetrating a certain distance into the tube, it ceases to move forward. The cilia, however, continue to move for some time, finally coming to rest. If the spermatozoon is carried out of the tube by the out-going under-current (see p. 556) the cilia recommence their motion. As less and less concentrated diffusion zones are reached the cilia move more and more rapidly. The spermatozoon soon begins to move slowly forward, the progression being in almost a straight line usually away from the mouth of the tube. Having arrived in the normal medium the organism moves more rapidly, but

1 Useless reactions are also admitted by Goebel, Ueber Studium und Auffassung der Anpassungserscheinungen bei Pflanzen, Festrede, Akad. d. Wiss., München, I 898 , p. I5.

${ }^{2}$ A. Fischer among others. Untersuchungen uiber Bacterien, Jahrb. f. wiss. Bot., 1895, p. 75 . 
still for a while in a fairly straight line. After a few minutes the spermatozoon moves once more at the normal rate and in the normal manner. The latter may be roughly described as a revolution in more or less complete circles about an ever-changing centre. I have noticed the above facts a considerable number of times in experiments with concentrated solutions. Recovery has taken place after a spermatozoon has been motionless for five minutes. Cessation of movement and death are therefore by no means necessarily simultaneous, as has been previously assumed ${ }^{1}$.

In order to determine the manner in which movement is affected by concentration the following method was used. Glass rings (Io $\mathrm{mm}$ high $\times 20 \mathrm{~mm}$ broad) were fastened upon microscope slides by means of a mixture of wax and fat, and fitted with cover-glasses. A little of the solution to be tested was poured into the chamber, and a hanging drop made. To the latter a single prothallium, after being well washed in part of the same solution, was added. The coverglass was sealed with vaseline. By this method the spermatozoa were directly liberated into the solution to be tested. The solution could not alter appreciably in concentration, and oxygen had free access to it.

The solutions were made isotonic with $\mathrm{I}, \frac{1}{2}, \frac{1}{5}, \frac{1}{10}, \frac{1}{20}$ and $\frac{1}{100}$ mol potassium nitrate. The solvent was tap-water.

In Table $\mathrm{V}, \mathrm{F}$ indicates that the spermatozoa moved forward,

C " " only the cilia moved,

O $" \quad$ there was no movement at all.

At the two highest concentrations of the salts and sugar spermatozoa were only rarely set free. The experiments were carried out with the spermatozoa of Gymnogramme Martensii. In the case of alcohol, potassium nitrate and cane-sugar similar results were obtained on repetition with the spermatozoa of Pteris serratula.

${ }^{1}$ Pfeffer, loc. cit., Bd. i, p. $3^{8}$. 
TABLE V.

\begin{tabular}{|c|c|c|c|c|c|c|c|c|}
\hline $\begin{array}{l}\text { Standard solutions of } \\
\text { potassium nitrate }\end{array}$ & \multicolumn{2}{|c|}{$\begin{array}{l}\text { in parts of a mol } \\
\text { in grams per cent. }\end{array}$} & $\begin{array}{c}\text { I } \\
\text { IO.I }\end{array}$ & $\begin{array}{c}\frac{1}{2} \\
5 \cdot 05\end{array}$ & $\begin{array}{l}\frac{1}{5} \\
2\end{array}$ & $\begin{array}{l}\frac{1}{10} \\
1 \cdot 0\end{array}$ & $\begin{array}{l}\frac{1}{20} \\
0.5\end{array}$ & $\begin{array}{l}\frac{1}{10} \overline{1} \\
0.1\end{array}$ \\
\hline Potassium nitrate & $\mathrm{KNO}_{3}$ & IOI & 0 & 0 & $\mathrm{C}$ & $\mathrm{F}$ & $\mathrm{F}$ & $\mathrm{F}$ \\
\hline Sodium chloride & $\mathrm{NaCl}$ & $5^{8 \cdot 5}$ & 0 & 0 & $\mathrm{C}$ & $\mathrm{F}$ & $\mathrm{F}$ & $\mathrm{F}$ \\
\hline Cane sugar & $\mathrm{C}_{12} \mathrm{H}_{22} \mathrm{O}_{11}$ & $34^{2}$ & 0 & 0 & $\mathrm{C}$ & $\mathrm{F}$ & $\mathrm{F}$ & F \\
\hline Glycerine & $\mathrm{C}_{3} \mathrm{H}_{5}(\mathrm{OH})_{3}$ & $9^{2}$ & $\mathrm{~F}$ & $\mathrm{~F}$ & $\mathrm{~F}$ & $\mathrm{~F}$ & $\mathrm{~F}$ & $\mathrm{~F}$ \\
\hline Alcohol & $\mathrm{C}_{2} \mathrm{H}_{6} \mathrm{O}$ & 46 & $\mathrm{~F}$ & $\mathrm{~F}$ & F & $\mathrm{F}$ & $\mathrm{F}$ & $\mathrm{F}$ \\
\hline
\end{tabular}

From the above Table it will be noticed that at the concentration $\frac{1}{10} \mathrm{~mol}$ potassium nitrate, sodium chloride and cane-sugar the spermatozoa move forward. The movement is, however, not so rapid as at $\frac{1}{20}$. At the concentration $\frac{1}{100}$ mol movement takes place in the same manner as in tap-water alone. At the concentration $\frac{1}{5} \mathrm{~mol}$ the spermatozoa are still liberated, but after being set free from their mother-cells only move their cilia, and are not capable ${ }^{1}$ of moving forward through the medium. The movement of the cilia often lasts a long time. I have watched such movement in $2.05 \mathrm{gm}$ per cent. potassium nitrate for an hour. A certain number of spermatozoa liberated at the concentrations $\frac{1}{10}$ and $\frac{1}{5} \mathrm{~mol}$ never move at all. At the concentration $\frac{1}{2} \mathrm{~mol}$ a few antheridia burst, but no motion of the spermatozoa was observed.

The spermatozoa were able to move forward in all the solutions of glycerine and alcohol tested. The difference in the behaviour of the organisms in solutions of these substances and in solutions of potassium nitrate, sodium chloride and sugar, is to be accounted for by the fact that the former two substances ${ }^{2}$ rapidly penetrate living cell-membranes, whereas the latter three are practically excluded from penetrating at all. Solutions of alcohol and glycerine do not therefore cause the same physical disturbance, namely the

1 Exceptionally a spermatozoon struggles a very short distance and very slowly through the medium.

${ }^{2}$ For literature, see p. $55^{6}$. 
withdrawal of water, as the salts and sugar. The movement in alcohol and glycerine at high concentrations is not surprising if we draw what seems to be the justifiable conclusion that the rate of motion of spermatozoa varies (within certain limits) as the amount of water they contain.

Glycerine penetrates living membranes much more slowly than alcohol. In my experiments it was found that at the concentration I mol of glycerine the spermatozoa did not immediately begin to move forward after liberation. After lying motionless for a short time they began to move slowly forward, at length reaching a maximum speed. In an isotonic solution of alcohol the spermatozoa moved quite rapidly as soon as liberated. The difference in the rate of penetration of the two substances into living membranes makes itself here clearly apparent. Glycerine requires a considerable time to penetrate. Hence the recovery of the spermatozoa. Alcohol penetrates almost instantaneously. Hence the rapid movement of the spermatozoa at the concentration I mol of this substance immediately after their liberation.

It was noticed that the spermatozoa did not move so rapidly in $\frac{1}{10} \mathrm{~mol}$ potassium nitrate as in $\frac{1}{10} \mathrm{~mol}$ cane-sugar. This result, which was repeated several times, may possibly be accounted for by the more toxic action of the salt. It may, however, indicate that the membranes of the organisms are to a slight degree penetrable by cane-sugar.

\section{LENGTH OF THE SWARM-PERIOD.}

According to Strasburger ${ }^{1}$ the swarm-period for the spermatozoa of Pteris serratula is not more than half an hour, while for Ceratopteris thalictroides it is scarcely twenty minutes. Voegler ${ }^{2}$ has confirmed the latter observation and has also made the following additional swarm-period determinations:-Gymnogramme Laucheana, twenty-five minutes;

1 Strasburger, Die Befruchtung bei den Farnkräutern. Jahrb. f. wiss. Bot., I86970, Bd. vii, p. 396.

2 Voegler, loc. cit., Bot. Zeit., 189I, pp. 646-648. 
Dicksonia antarctica, fifty to fifty-five minutes; Blechmum occidentale, thirty-five to forty minutes; species of Alsophila, Polypodium, Asplenium, Neprolepis and Osmunda, twentyfive to forty minutes. My own observations on Gymnogramme Martensii differ considerably from those made by Strasburger and Voegler for other spermatozoa. The swarmperiod for this species is about 120 minutes.

In determining the length of the swarm-period, I have used the hanging-drop method already described (p. 573). A single prothallium with few antheridia was placed in a drop. It was thereby possible to watch the liberation of the spermatozoa. Several antheridia usually burst almost simultaneously. When it was thought that no more antheridia would burst the prothallium was allowed to remain in the drop. If the contrary was feared the prothallium was removed.

The time intervening between placing the prothallia in water and the bursting of the antheridia varies according to the ripeness of the latter. In a considerable number of experiments the time was ten to twenty minutes. After an antheridium has burst several minutes, often about eight, are required before the spermatozoa have all become set free from the mother-cells. In a few cases individual spermatozoa after liberation from an antheridium did not swarm at all. Sometimes a few spermatozoa were left in an antheridium after the others had escaped and there continued to move for a considerable time.

It was found that in tap-water the majority of spermatozoa move well for about two hours, after which they come to rest one by one, the longest time of movement being about three hours. This result is somewhat remarkable in view of the already quoted, much briefer swarm-periods given by Strasburger and Voegler for other spermatozoa. In particular, Voegler's estimation of the swarm-period for Gymnogramme Laucheana is only twenty-five minutes. According to my estimation the swarm-period for the nearly related G. Martensii must be considered at least five times as long. 
The detrimental effect of distilled water upon the life of spermatozoa has already been remarked by Pfeffer ${ }^{1}$. In my experiments with hanging drops of distilled water it was found that the majority of spermatozoa came to rest in about thirty minutes, the longest time of movement being just one hour. The swarm-period was thus reduced to less than onethird of that obtained with tap-water. The distilled ${ }^{2}$ water was not shaken up before use. I was under the impression that the shallow hanging drops exposed to the air in the glass-cells would almost immediately become saturated with oxygen. From the work of Senn ${ }^{3}$, with which I have since become acquainted, this appears to have been a mistake. Senn found that in hanging drops of distilled water which had not been shaken up with air Coelastrum reticulatum formed colonies or coenobia. In similar drops of distilled water which had been previously shaken up with air the Alga gave rise to single unconnected cells. The difference in the behaviour of the Alga in the two cases is due to the different amount of oxygen in the drops. Similarly the difference in the amount of oxygen in hanging drops of tap-water and of distilled water may determine the difference in the swarmperiod of spermatozoa in the two cases.

Pfeffer ${ }^{4}$ found that spermatozoa swarmed at least twice as long in an open drop of water as in an ordinary coverglasspreparation where the coverglass was supported by strips of paper, and at least five times as long as in an ordinary preparation not so supported. He attributed the differences in the length of the swarm-periods to the amount of oxygen present in the different cases. It is to be regretted that neither Strasburger nor Voegler have stated the exact methods which they employed in determining swarm-periods. If coverglasspreparations, which indeed Voegler ${ }^{5}$ appears to have used, or hanging drops made with unshaken distilled water were

1 Pfeffer, loc. cit., Bd. i, p. 368 , Anm. 3 .

${ }^{2}$ Doubly distilled and put in a specially cleaned two-litre flask.

${ }^{3}$ Senn, Ueber einige coloniebildende einzellige Algen. Dissertation, Basel, 1899, p. I3.

${ }^{4}$ Pfeffer, loc. cit., Bd. i, p. 372 . ${ }^{5}$ Voegler, loc. cit., p. 646.

Q q 2 


\section{Buller.-Contributions to our Knowledge of the}

employed, much briefer swarm-periods would certainly result than would be the case if the spermatozoa were liberated in hanging drops of tap-water. With similar conditions it seems not improbable that there would be no great difference in the length of the swarm-periods of Gymnogramme Laucheana and G. Martensii.

Weak solutions of alcohol ${ }^{1}$ made with tap-water were found to be less deleterious than the distilled water. Thus in I.5 gm per cent. the spermatozoa move as long as in tapwater. In two experiments the times of longest movement were determined to be two hours fifty-eight minutes and three hours twenty-five minutes respectively. In each case the majority of spermatozoa moved well for about Ioo minutes. With increasing concentration, however, the injurious effect of the alcohol becomes obvious. Thus in $6.9 \mathrm{gm}$ per cent., although the spermatozoa move rapidly at first they come to rest in fifteen minutes. The fact, however, that the movements last so long in such concentrated solutions of alcohol proves that this substance is not so toxic as is often supposed.

In glycerine I have been unable to detect any toxic action. When spermatozoa are liberated in a hanging drop of 13.8 . gm per cent. (the solution being made with tap-water) they are at first motionless, but after a few minutes begin to move slowly, gradually obtaining a maximum speed. It is probable that during this process the glycerine penetrates into the protoplasm. Some spermatozoa, however, do not recover and never move in these strong solutions. Although the motion is not so lively the swarm-period is quite as long in I 3.8 or $6.9 \mathrm{gm}$ per cent. ${ }^{2}$ glycerine as in tap-water.

Acids are very toxic. Malic and tartaric acids are about equal in their effects. Thus at $0.01 \mathrm{gm}$ per cent. the sper-

\footnotetext{
${ }^{1}$ In these experiments, as in all those made with the glass rings, the chamber was about half filled with the solution of which the hanging drop was made.

${ }^{2}$ In some experiments with this concentration movement still took place more than four hours after removal of the prothallia from the drops. Since some of the spermatozoa may have begun to move after lying some time motionless in the glycerine it cannot be assumed without further experiment that they swarm longer in a solution of glycerine than in tap-water.
} 
matozoa do not move more than about ten minutes, and even at a concentration of $0.00 \mathrm{I}$ per cent. the swarm-period is reduced to about two-thirds the normal.

The swarm-period is also much reduced when the spermatozoa are liberated in solutions of neutral substances which are concentrated enough to withdraw a considerable quantity of water from the organisms. Thus at a concentration isotonic with 2 per cent. potassium nitrate there is no forward movement, no swarming, for either cane-sugar, potassium nitrate or sodium chloride. At concentrations isotonic with I per cent. potassium nitrate swarming takes place, but its period is much reduced. If, however, the hanging drops are isotonic with 0.1 per cent. potassium nitrate, the swarming is as active as in tap-water alone. The swarm-periods in these weak solutions were not exactly observed, but after forty minutes the spermatozoa were seen to move as actively as in similar experiments with tap-water.

\section{ThE Starch IN THE VESICLE.}

It is well known that the spermatozoa of the Ferns carry with them a vesicle attached to the hinder end of their bodies. In this vesicle is usually a considerable quantity of starch in the form of small grains.

The starch can readily be distinguished in the living spermatozoa whenever they move slowly enough for the purpose. It appears to occur under normal conditions in all freshly liberated spermatozoa. If a prothallium be plunged in a solution of iodine, the antheridia become more darkly stained than any of the vegetative cells. This is due to the relatively large amount of starch stored up in the mothercells of the spermatozoa. The starch grains, often about ten in number, are chiefly collected on the side of attachment of the vesicle.

According to Strasburger ${ }^{1}$ the spermatozoa, on being attracted toward the archegonia, lose their vesicles in the

${ }^{1}$ Strasburger, Die Befruchtung bei den Farnkräutern, loc. cit., p. 403. 


\section{Buller.-Contributions to our Knowledge of the}

slime at the mouth. The vesicles are somewhat sticky, and sometimes become attached to various objects. A spermatozoid, in struggling to get free, may break away from its vesicle and lose it. Pfeffer ${ }^{1}$, however, has observed that, as a rule, the vesicle remains attached during the whole of the swarm-period. This is certainly the case with Gymnogramme Martensii.

Pfeffer ${ }^{2}$ made some experiments to determine whether the starch disappeared during the swarm-period. He killed spermatozoa after they had been liberated for an hour, and compared the quantity of starch contained in the vesicles with that in the vesicles of spermatozoa when just set free. Although the quantity of starch appeared to have somewhat diminished during the swarm-period, he was obliged to admit, having repeated the experiment twice, that the result was not decisive.

It has already been stated that the spermatozoa of Gymnogramme Martensii move well for about two hours, after which they gradually come to rest, the time of longest movement being about three hours. I decided, therefore, to compare the amount of starch present in spermatozoa just liberated and such in spermatozoa after three hours' freedom. Similar prothallia from the same pot were used. The experiments were repeated three times. It was found that the starch had either greatly diminished in quantity or had disappeared entirely. A considerable number of spermatozoa, after being stained with iodine, were seen to be quite free from starch. On the contrary, all the freshly liberated spermatozoa contained the usual quantity, the large and small grains becoming very clear with the iodine reaction.

From the foregoing result, it would seem that Pfeffer's suggestion that the starch may be used as a food material during the swarm-period is justified, at any rate in the case of Gymnogramme Martensii. If, however, the swarm-periods for the spermatozoa of other species of Ferns are as short as those given by Strasburger and Voegler it is very doubtful,

1 Pfeffer, loc. cit., Bd. i, p. 370.

${ }^{2}$ Ibid. 
Physiology of the Spermatozoa of Ferns. $58 \mathrm{I}$

especially in view of the experiments of Pfeffer, if the starch has in general the significance here given it.

The vesicle swells considerably during the swarm-period, and must occasion considerable resistance in the motion of the spermatozoa through the water. If, however, the starch is used up as food this disadvantage might be more than compensated, and the arrangement of the spermatozoid and its vesicle be likened to a locomotive with its well-stored tender attached behind. It is, however, possible that the vesicle may be partly used to regulate the motion or as a balancing apparatus during the swarm-period. One can scarcely suppose that so comparatively large a structure is a useless vestige of the mother-cell.

\section{Summary of the Chief Results.}

In addition to malic acid and its salts many organic and inorganic salts widely occurring in cell-sap give the spermatozoa of Ferns a positive chemotactic stimulus.

Malic acid and its salts attract more strongly than any other substances tested.

It is not free malic acid, but may be one of its salts, which plays the chief rôle in attracting the spermatozoa to the archegonia.

Sugars, alcohols, asparagin, and urea do not attract.

The attracting neutral salts do not give an unmistakable tonotactic repulsion at high concentrations. If such a repulsion occurs it does not prevent the spermatozoa from finally entering concentrated solutions where they are brought to rest by loss of water.

The repulsion given by malic and maleic acids is chemotactic. The dissociation theory of solutions gives a clue for understanding the chemotaxis of the spermatozoa.

The attracting of the spermatozoa by cell-sap is not a decisive proof of the presence in it of malic acid compounds, and may take place in their absence.

The withdrawal of a certain quantity of water from the 
582 Buller.-Physiology of the Spermatozoa of Ferns.

spermatozoa brings them to rest. Recovery takes place on reabsorption of the water. The protoplasm of the spermatozoa is penetrated very slowly or not at all by sugar and neutral salts, rapidly by glycerine, and very rapidly by alcohol.

The swarm-period of the spermatozoa of Gymnogramme Martensii is about 120 minutes. Previously determined swarm-periods are much shorter.

The starch in the vesicles of the spermatozoa of Gymnogramme Martensii disappears during the swarm-period.

The work for the above paper was done between November, 1898 , and August, 1899 , during the term of an $185_{1}$ Exhibition Scholarship, in the laboratory of Professor Pfeffer at Leipzig. I have much pleasure in acknowledging with my best thanks his kind advice and stimulating criticism. 


\section{$2 \mathrm{BHL}$ Biodiversity Heritage Library}

Buller, A. H. Reginald. 1900. "Contributions to our knowledge of the physiology of the spermatozoa of ferns." Annals of botany 14, 543-582. https://doi.org/10.1093/oxfordjournals.aob.a088792.

View This Item Online: https://www.biodiversitylibrary.org/item/238259

DOI: https://doi.org/10.1093/oxfordjournals.aob.a088792

Permalink: https://www.biodiversitylibrary.org/partpdf/318599

\section{Holding Institution}

Smithsonian Libraries

\section{Sponsored by}

Biodiversity Heritage Library

\section{Copyright \& Reuse}

Copyright Status: Not in copyright. The BHL knows of no copyright restrictions on this item.

This document was created from content at the Biodiversity Heritage Library, the world's largest open access digital library for biodiversity literature and archives. Visit BHL at https://www.biodiversitylibrary.org. 